\title{
Progressive Multifocal Leukoencephalopathy Presenting with Bilateral Myoclonus: A Case Report
}

\author{
Bilateral Miyoklonus ile Ortaya Çıkan Progresif Multifokal Lökoensefalopati: \\ Bir Olgu Sunumu
}

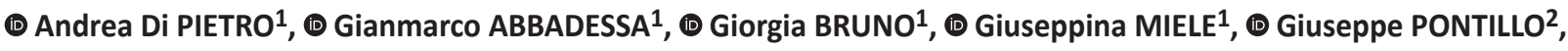 \\ (1) Sirio COCOZZA², (1) Anna Maria SPERA ${ }^{3}$, (1) Gianfranco PUOTI ${ }^{1}$ \\ 1 University of Campania 'Luigi Vanvitelli, Department of Advanced Medical and Surgical Sciences, Naples, Italy \\ 2 University Federico II of Naples, Department of Advanced Biomedical Sciences, Naples, Italy \\ 3 University of Salerno, Department of Infectious Diseases and Clinical Microbiology, Salerno, Italy
}

\section{Abstract}

Progressive multifocal leukoencephalopathy (PML) is a demyelinating disease of the central nervous system (CNS) caused by John Cunningham virus lytic infection of the oligodendrocytes, the myelin-producing cells in the CNS. Symptoms largely vary depending on location and size of the lesions, and the most frequent clinical presentation is characterized by motor deficits, altered consciousness, gait ataxia, and visual symptoms. Despite limb weakness or hemiparesis as the most frequent presenting symptom, involuntary movement is far less common, and very few cases are described in the literature with focal movement disorders without additional neurologic abnormalities. Here we described a case of PML in a patient treated for non-Hodgkin lymphoma with immunomodulatory chemotherapies who presented with bilateral myoclonus of the upper limbs. This report highlights the importance of considering PML in the differential diagnosis of focal movement disorders and discusses the potential causative mechanism of this atypical presentation.

Keywords: Progressive multifocal leukoencephalopathy, movement disorder, immunosuppression, magnetic resonance imaging

\section{$\ddot{O z}$}

Progresif multifokal lökoensefalopati (PML), merkezi sinir sisteminde (MSS) miyelin üreten hücreler olan oligodentrositlerin John Cunningham virüsü litik enfeksiyonu sonucu gelişen MSS'nin demiyelinizan bir hastalığıdır. Semptomlar lezyonların yeri ve büyüklüğüne bağlı olarak büyük ölçüde değişiklik gösterir ve en sık görülen klinik tablo motor bozukluklar, bilinç bozukluğu, ataksi ve görme semptomları ile karakterizedir. Başvuruda en sık karşılaşılan semptom ekstremitelerde güçsüzlük veya hemiparezi iken istemsiz hareketler çok daha nadir görülmektedir ve literatürde ek nörolojik hastalık olmaksızın fokal hareket bozukluğu görülen az sayıda olgu bildirilmiştir. Bu yazıda, üst ekstremitelerin bilateral miyoklonusu ile başvuran, non-Hodgkin lenfoma için immünmodülatör kemoterapiler ile tedavi edilmekte olan bir PML olgusu sunulmaktadır. Bu olgu sunumu, fokal hareket bozukluklarının ayırıcı tanısında PML'nin dikkate alınmasının önemini vurgulamakta ve bu atipik olguların potansiyel nedensel mekanizmasını tartışmaktadır.

Anahtar Kelimeler: Progresif multifokal lökoensefalopati, hareket bozukluğu, immünosüpresyon, manyetik rezonans görüntüleme

Cite this article as: Di Pietro A, Abbadessa G, Bruno G, Miele G, Pontillo G, Cocozza S, Spera AM, Puoti G. Progressive Multifocal Leukoencephalopathy Presenting with Bilateral Myoclonus: A Case Report. Mediterr J Infect Microb Antimicrob. 2020;9:6. 


\section{Introduction}

Progressive multifocal leukoencephalopathy $(P M L)$ is a demyelinating disease of the central nervous system caused by John Cunningham virus (JCV) infection of the olygodendrocytes. JCV is a circular, double-stranded DNA virus of the Polyomaviridae family. It is ubiquitous; 50-90\% of adults have been exposed to this virus, and seroprevalence increases with age, but it is not necessarily associated with disease development ${ }^{[1]}$. Immunocompromised individuals are at risk of many uncommon diseases, which can manifest with aspecific symptoms leading to considerable delay in diagnosis and increase in mortality ${ }^{[2-4]}$. In immunocompromised patients, JCV activation can lead to virus dissemination from latency sites, including the brain. Since its initial description as a fatal syndrome in 1958 in hematologic disorders ${ }^{[5]}$, its incidence increased in the 1980s due to the emergence of the HIV infection. Recently, a growing number of cases have been described in immunocompromised hosts treated with certain drugs, including monoclonal antibodies ${ }^{[6]}$. Despite the risk of JCV reactivation being widely described in patients affected by hematologic disorders, its occurrence has also been extensively associated with other types of immunocompromised conditions, including patients with HIV infection, transplant recipients ${ }^{[7]}$, or patients treated with monoclonal antibodies ${ }^{[6]}$. Its extremely heterogeneous presentation could lead to diagnostic difficulty or mistakes. Indeed, symptoms largely vary depending on the location and size of the lesions, and most frequently, the clinical presentation is characterized by motor deficits, altered consciousness, gait ataxia, and visual symptoms ${ }^{[7]}$. Despite limb weakness or hemiparesis as the most frequent presenting symptom, involuntary movement is far less common and typical of different disorders other than $\mathrm{PML}^{[8]}$. Therefore, at present, very few cases with focal movement disorders without additional neurologic abnormalities are described in the literature ${ }^{[9-13]}$.

\section{Case Report}

A 66-year-old man was admitted to our clinic because of a history of involuntary jerky movements and clumsiness that initially involved the right arm and the left arm five months later. The patient had been diagnosed with non-Hodgkin lymphoma one year before and treated with a combination of rituximab, cyclophosphamide, hydrochloride doxorubicin, vincristine, and prednisone (R-CHOP). He underwent his last chemotherapy cycle two months before the onset of neurological symptoms and was considered to be in clinical remission. He was also found positive for $\lg \mathrm{M}$ antibodies due to a previous diagnosis of osteoarticular brucellosis ${ }^{[14]}$; no other significant data were collected at anamnestic and laboratory examination. At the time of presentation, the neurological examination revealed irregular myoclonic jerks affecting both upper limbs with distal predominance and more expressed at the right side. He had slight upper limb weakness with distal distribution. Subtle movements of the hands were clumsy and inaccurate, and deep tendon reflexes were diffusely increased, particularly at the right arm, with normal plantar flexor response. Blood tests showed a white cell count of $9.12 \times 10^{9} / \mathrm{L}$, with a lymphocyte count of $1.17 \times 10^{9} / \mathrm{L}$. Electroencephalography (EEG) showed bilateral temporal irritative anomalies.

The first brain magnetic resonance imaging (MRI) performed six weeks before our observation showed cortical hyperintensity on T2-, fluid-attenuated inversion recovery (FLAIR) and diffusion weighted imaging at the level of both the pre-rolandic gyrus (asymmetric for left prevalence) and left inferior occipital
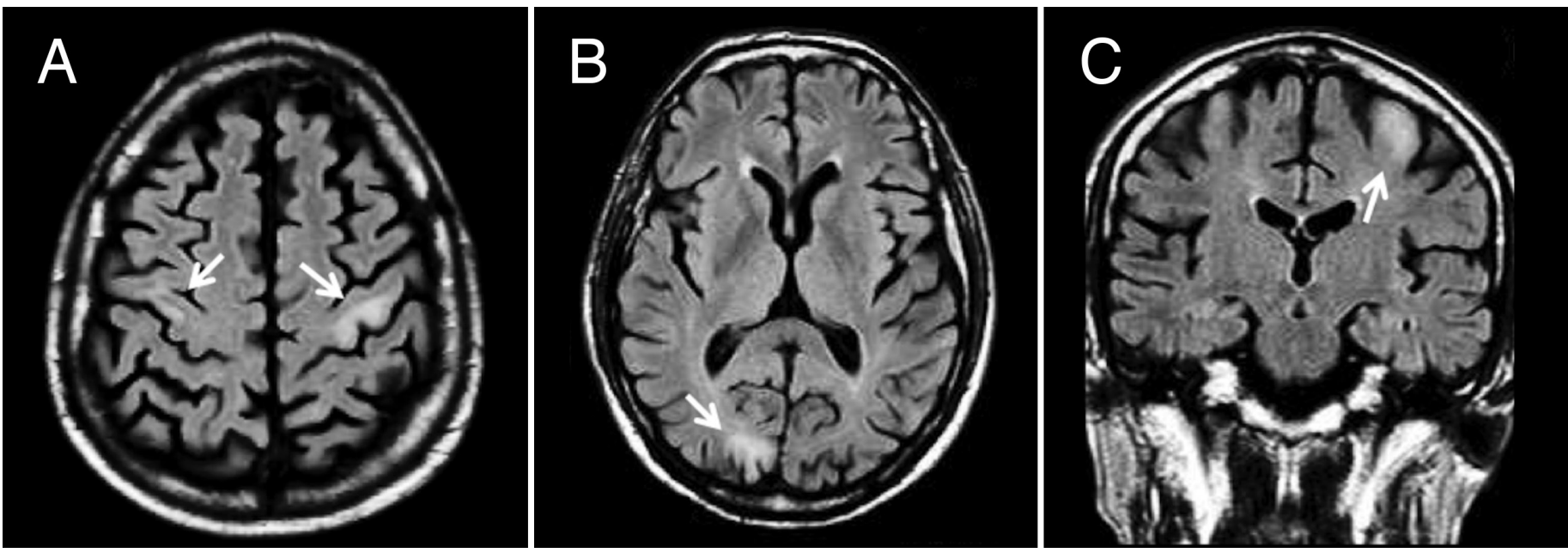

Figure 1. Brain magnetic resonance imaging [fluid-attenuated inversion recovery sequence, axial (A, B) and coronal (C) sections] showing areas of hyperintense signal alteration of the right occipital subcortical white matter (B) and the prerolandic cortex and subcortical white matter bilaterally (, , ; arrows), more extended on the left 
gyrus. Neither contrast enhancement nor brain susceptibility changes $^{[15]}$ were detected (Figure 1). EEG showed irritative temporal anomalies. The second brain $\mathrm{MRI}$, acquired at hospitalization, revealed that the volume of the lesions was slightly increased, as well as the signal intensity in T2 and FLAIR sequences. No new lesion was detected. The cerebrospinal fluid (CSF) was clear and acellular, with no organisms seen on Gram and India ink stain and a negative cryptococcal antigen test; biochemical analysis showed an increased protein level of 0.81 $\mathrm{g} / \mathrm{l}$ (normal 0.15-0.45 g/l), but CSF/serum glucose ratio (0.63) was normal. Real-time polymerase chain reaction found JCV DNA copies in the CSF $(21,217$ copies $/ \mathrm{ml})$, confirming the diagnosis of PML. The myoclonic jerks and weakness of the upper limbs slightly worsened over the following weeks. The patient died because of a pulmonary infection eight months after the onset of neurological disease.

Written informed consent was obtained from the patient and his parents.

\section{Literature Review}

The PML clinical spectrum of presentation varies widely depending on the distribution of demyelinating lesions in the brain $^{[16]}$. To the best of our knowledge, to date, only three patients with PML presenting with myoclonus have been described in the literature. In two of these cases, myoclonus was part of a mixed movement disorders. The first one presented involuntary jerky movements affecting the thumb and fingers of the left hand at rest with additionally mild dystonic postures of the fingers and episodes of irregular distal arm tremor during voluntary activity $^{[8]}$, whereas the second one developed generalized myoclonus in addition to gait ataxia and intention tremor ${ }^{[9]}$. The third patient, described by Rittweger et al. ${ }^{[13]}$, presented with focal isolated myoclonus of the left arm associated with the "U" fibers under the precentral gyrus of the right hemisphere on brain MRI.

\section{Discussion}

In this study, we described a case of a patient with PML with bilateral myoclonus of the upper limbs who was treated with immunomodulatory chemotherapies for non-Hodgkin lymphoma. The PML can affect many different categories of patients, including subjects with hematologic disorders, HIV infection, transplant recipients ${ }^{[7]}$, or patients treated with monoclonal antibodies ${ }^{[6]}$. Furthermore, the clinical spectrum of presentation varies widely depending on the distribution of demyelinating lesions in the brain. Limb weakness due to pyramidal system involvement represents the most common presentation. By contrast, movement disorders are very rare, with reported incidence of $0-2.6 \%{ }^{[16]}$. Similar to previously reported cases ${ }^{[8,9,13]}$, our patient insidiously developed a focal isolated myoclonus and weakness of the right arm, but he soon developed the same symptoms contralaterally, and brain MRI showed bilateral involvement not only of the "U" fibers of both prerolandic cortices, but also a corresponding cortical involvement. Other reported cases showed atypical clinical manifestation due to gray matter involvement ${ }^{[17]}$, but this is the first time that the JCV lesions spread through the corpus callosum to the correspondent contralateral brain cortical area. In this direction, Wüthrich et al. ${ }^{[18]}$ showed the presence of viral proteins in the nuclei, cytoplasm, and axons of neurons, suggesting that JCV might spread in the brain by migrating through the axons of infected neurons.

\section{Conclusion}

In conclusion, this case report highlights the complex pathological mechanism underlying PML and emphasizes that JCV infection should be considered as part of the differential diagnosis of focal movement disorder, especially in patients with atypical MRI features where the diagnosis is more challenging for the physician, and possible mimickers should be excluded $^{[19-23]}$.

\section{Ethics}

Informed Consent: Written informed consent was obtained from the patient and his parents.

Peer-review: Externally and internally peer-reviewed.

\section{Authorship Contributions}

Surgical and Medical Practices: A.D.P., G.A., G.B., G.M., G.P., Concept: A.D.P., G.A., G.B., G.M., G.P., Design: A.D.P., G.A., G.B., G.M., G.P., Data Collection or Processing: G.Po., S.C., A.M.S., Analysis or Interpretation: A.D.P., G.A., G.B., G.P., G.Po, S.C., Literature Search: B.G., P.G., G.Po., S.C., A.M.S., Writing: A.D.P., G.A., G.B., G.M., G.P., A.M.S.

Conflict of Interest: No conflict of interest was declared by the authors.

Financial Disclosure: The authors declared that this study received no financial support.

\section{References}

1. Henson J, Saffer J, Furneaux H. The transcription factor Sp1 binds to the JC virus promoter and is selectively expressed in glial cells in human brain. Ann Neurol. 1992;32:72-7.

2. Pagliano P, Boccia G, De Caro F, Esposito S. Bacterial meningitis complicating the course of liver cirrhosis. Infection. 2017:45:795-800.

3. Pagliano P, Attanasio V, Rossi M, Ascione T, Frangaze F, Sarno Di R, Conte $M$, Faella FS. Pneumococcal meningitis in cirrhotics: distinctive findings of presentation and outcome. J Infect. 2012;65:577-9.

4. Pagliano $P$, Carannante $N$, Gramiccia M, Ascione T, Stornaiuolo G, Gradoni L, Faella FS, Gaeta GB. Visceral leishmaniasis causes fever and decompensation in patients with cirrhosis. Gut. 2007;56:893-4. 
5. Åstrom KE, Mancall EL, Richardson EP. Progressive multifocal leukoencephalopathy; a hitherto unrecognized complication of chronic lymphatic leukaemia and Hodgkin's disease. Brain. 1958;81:93-111.

6. Bohra C, Sokol L, Dalia S. Progressive Multifocal Leukoencephalopathy and Monoclonal Antibodies: A Review. Cancer Control. 2017;24:1073274817729901.

7. Bruno G, Miele G, Abbadessa G, Di Pietro A, Russo C, Negro A, Bonavita S, Puoti G. Atypical progressive multifocal leukoencephalopathy in a kidney transplant recipient with improving symptoms after immunocompetence recovery. Infez Med. 2020;28:87-90.

8. Striano P, Tortora F, Evoli A, Palmieri G, Elefante A, Zara F, Tarr PE, Striano S. Periodic myoclonus due to cytomegalovirus encephalitis in a patient with good syndrome. Arch Neurol. 2007;64:277-9.

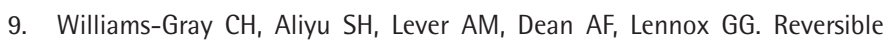
parkinsonism in a patient with progressive multifocal leucoencephalopathy. J Neurol Neurosurg Psychiatry. 2007;78:408-10.

10. Rieder CRM, Ziomkowski SC. Head tremor and progressive multifocal leukoencephalopathy in AIDS patients: report of two cases. Arq Neuropsiquiatr. 2005;63:150-3.

11. Stockhammer G, Poewe W, Wissel J, Kiechl U, Maier H, Felber S. Progressive multifocal leukoencephalopathy presenting with an isolated focal movement disorder. Mov Disord. 2000;15:1006-9.

12. Fontoura $P$, Vale J, Lima C, Scaravilli F, Guimarães J. Progressive myoclonic ataxia and JC virus encephalitis in an AIDS patient. J NeurolNeurosurg Psychiatry. 2002;72:653-6.

13. Rittweger $M$, Branding $G$, Arastéh $K$, Grosse P, Katchanov J. Teaching Video Neurolmages: focal cortical myoclonus in progressive multifocal leukoencephalopathy. Neurology. 2014;83:e132.

14. de Divitiis 0 , Elefante A. Cervical spinal brucellosis: a diagnostic and surgical challenge. World Neurosurg. 2012;78:257-9.

15. Pontillo G, Cocozza S, Lanzillo R, Borrelli P, De Rosa A, Brescia Morra V, Tedeschi E, Palma G. Brain Susceptibility Changes in a Patient with
Natalizumab-Related Progressive Multifocal Leukoencephalopathy: A Longitudinal Quantitative Susceptibility Mapping and Relaxometry Study. Front Neurol. 2017;8:294.

16. Geschwind M, Skolasky RI, Royal WS, McArthur JC. The relative contributions of HAART and alpha-interferon for therapy of progressive multifocal leukoencephalopathy in AIDS. J Neurovirol. 2001;7:353-7.

17. Miskin DP, Koralnik IJ. Novel syndrome sassociated with JC virus infection of neurons and meningeal cells: no longer a gray area. Curr Opin Neurol. 2015;28:288-94.

18. Wüthrich C, Dang X, Westmoreland S, McKay J, Maheshwari A, Anderson MP, Ropper AH, Viscidi RP, Koralnik IJ. Fulminant JC virus encephalopathy with productive infection of cortical pyramidal neurons. Ann Neurol. 2009;65:742-8.

19. Cocozza S, Russo C, Pontillo G, Ugga L, Macera A, Cervo A, De Liso M, Di Paolo N, Ginocchio MI, Giordano F, Leone G, Rusconi G, Stanzione A, Briganti F, Quarantelli M, Caranci F, D'Amico A, Elefante A, Tedeschi E, Brunetti A. Is advanced neuroimaging for neuroradiologists? A systematic review of the scientific literature of the last decade. Neuroradiology. 2016;58:1233-9.

20. Elefante A, Puoti G, Senese R, Coppola C, Russo C, Tortora F, de Divitiis O, Brunetti A. Non-alcoholic acute Wernicke's encephalopathy: role of MRI in non typical cases. Eur J Radiol. 2012;81:4099-104.

21. Ottaviano G, Cantone E, D'Errico A, Salvalaggio A, Citton V, Scarpa B, Favaro A, Sinisi AA, Liuzzi R, Bonanni G, Di Salle F, Elefante A, Manara R, Staffieri A, Martini A, Brunetti A. Sniffin' Sticks and olfactory system imaging in patients with Kallmann syndrome. Int Forum Allergy Rhinol. 2015;5:855-61.

22. Völker HU, Kraft K, Arnold E, Steinhoff S, Kolios G, Sommer S. Progressive multifocal leukoencephalopathy developing in advanced pulmonal sarcoidosis. Clin Neurol Neurosurg. 2007;109:624-30.

23. Capalbo D, Elefante A, Spagnuolo MI, Mazza C, Betterle C, Pignata C, Salerno M. Posterior reversible encephalopathy syndrome in a child during an accelerated phase of a severe APECED phenotype due to an uncommon mutation of AIRE. Clin Endocrinol (0xf). 2008;69:511-3. 